\title{
ALEKSANDER MAZIARZ1
}

\section{Program łagodzenia kar Leniency jako instrument służący wykrywaniu karteli}

Wpłynął: 19.04.2020. Akceptacja 10.02.2021

\section{Streszczenie}

Celem badań jest analiza unijnych regulacji dotyczących programu łagodzenia kar w prawie konkurencji i wpływu tego programu na wykrywalność karteli. Przede wszystkim zbadano cel $i$ istotę programu łagodzenia kar, dokonano analizy obecnie obowiązującego w prawie UE programu łagodzenia kar zakładającego całkowitą oraz częściową redukcję kary pieniężnej grożącej przedsiębiorstwu oraz zbadano różnice występujące w prawie amerykańskim.

W artykule wykorzystano metodę formalno-dogmatyczną oraz prawno-porównawczą - w głównej mierze sięgnięto do rozwiązań amerykańskich. Tezą artykułu jest stwierdzenie, że program łagodzenia kar nie powinien być traktowany jako główny instrument służący wykrywaniu karteli, a jedynie jako jedno uzupełnienie innych sposobów. Wyniki badań mogą być zastosowane do dalszych badań nad wykrywaniem karteli.

Słowa kluczowe: program łagodzenia kar, leniency, kartel, porozumienie ograniczające konkurencję.

1 Dr hab. Aleksander Maziarz, prof. ALK-Akademia Leona Koźmińskiego (Polska); e-mail: amaziarz@ kozminski.edu.pl; ORCID: 0000-0002-0482-5400. 


\title{
ALEKSANDER MAZIARZ
}

\section{Leniency Program as an Instrument to Detect Cartels}

\begin{abstract}
The aim of the article is to analyze the EU regulations regarding the leniency program in competition law and its impact on cartel detection. First of all the purpose and substance of the leniency program have been analysed, moreover the article analyses EU regulations on partial and full leniency as well as differences with American competition law. The article uses the formal-dogmatic and legal-comparative resarch methods - mainly American solutions were used for comparision with EU law. The thesis of the article is the statement that the leniency program should not be considered as the main legal instrument for detecting cartels but it should complement other instruments. The research results can be used for further research on legal regulations which are used for detecting cartels.
\end{abstract}

Keywords: leniency program, cartel, agreement restricting competition. 


\section{Wprowadzenie}

Zwalczanie naruszeń prawa konkurencji jest jednym z podstawowych celów unijnego prawa konkurencji. Ma to zapewnić rozwój gospodarczy państw członkowskich i urzeczywistniać swobody gospodarcze przewidziane $\mathrm{w}$ traktatach. Jednak osiągnięcie tego celu nie jest łatwe, bowiem takie naruszenia prawa konkurencji, jakim są np. kartele (porozumienia ograniczające konkurencję) są bardzo trudne do wykrycia. Szacuje się, że od 10 do 33\% tego typu porozumień jest wykrywanych ${ }^{2}$, co zaś oznacza, że organa antymonopolowe obciążone są znaczną ilością pracy przy wykrywaniu i sankcjonowaniu przedsiębiorstw dokonujących naruszeń prawa konkurencji.

Komisja Europejska, będąc organem antymonopolowym, jest odpowiedzialna za prowadzenie wszystkich postępowań dotyczących naruszenia prawa konkurencji UE. Jednakże na podstawie rozporządzenia $1 / 2003^{3}$ część z tych postępowań mogą prowadzić krajowe organy antymonopolowe. W rezultacie Komisja Europejska zajmuje się jedynie najpoważniejszymi zachowaniami zakazanymi przez TFUE. Jednakże nadal ilość postępowań antymonopolowych, którymi zajmuje się Komisja, jest znaczna, co zaś powoduje, że postępowania te trwają latami. Przykładem mogą być chociażby ostanie prowadzone przez Komisję Europejską sprawy - Maritime Car Carriers czy Occupant Safety Systems (II), w których od momentu wszczęcia postępowania antymonopolowego do dnia wydania decyzji upłynęło kilka lat. Taki stan rzeczy powoduje zaś, że brakuje zasobów do wykrywania wszystkich przejawów naruszenia prawa konkurencji. Aby temu zapobiec, w prawie konkurencji UE wprowadzono program łagodzenia kar, którego celem jest odciążenie Komisji Europejskiej od czasochłonnego wykrywania karteli.

Celem niniejszego artykułu jest dokonanie analizy programu łagodzenia kar (leniency) pod kątem przydatności do wykrywania karteli. Instytucja te została wprowadzona do unijnego prawa konkurencji w celu poprawy wykrywalności karteli. Szczegółowe rozwiązania tych instytucji często mogą budzić wątpliwości, czy cel ten został osiągnięty, stąd tezą artykułu jest stwierdzenie, że program

2 J. Connor, Cartel Detection and Duration Worldwide, "Antitrust Chronicle” 2011, 9, s. 2.

3 Rozporządzenie $\mathrm{nr}$ 1/2003 w sprawie wprowadzenia w życie reguł konkurencji ustanowionych $\mathrm{w}$ art. 81 i 82 Traktatu, Dz. Urz. UE L 1/1 z 2003 r. 
łagodzenia kar nie powinien być traktowany jako główny instrument służący wykrywaniu karteli, a jedynie jako jedno uzupełnienie innych sposobów.

\section{Geneza i rozpowszechnienie programów łagodzenia kar}

Programy łagodzenia kar wywodzą się ze Stanów Zjednoczonych, które już w latach 90. zreformowały uprawnienia dochodzeniowe przysługujące organom prowadzącym postępowania antymonopolowe. $Z$ uwagi na funkcjonowanie na rynku amerykańskim tajnych karteli, których uczestnicy zawierali niejako „zmowę milczenia", sięgnięto do instrumentów prawa karnego związanych z gromadzeniem dowodów ${ }^{4}$. Jednak i to okazało się niewystarczające, bowiem wykrycie kartelu powodowało, że nadal każdy z jego uczestników miał w zasadzie ten sam cel. Celem tym było podważenie lub niedoprowadzenie do zgromadzenia wystarczających dowodów na udowodnienie przez organ antymonopolowy mechanizmu funkcjonowania kartelu i tym samym uniknięcie kary ${ }^{5}$. Wprowadzenie przez amerykański departament sprawiedliwości pierwszego programu łagodzenia kar w 1978 r. zapoczątkowało zmianę tej sytuacji, chociaż dopiero w 1993 r. dokonano znaczących zmian w tym programie, które okazały się skuteczne w wykrywaniu karteli. Na kanwie amerykańskiego sukcesu w wykrywania karteli program łagodzenia kar został już w 1996 r. wprowadzony do unijnego prawa konkurencji, który po kilku latach funkcjonowania doczekał się zmian w 2002 i 2006 r.

Wzrost wykrywalności karteli spowodowany wprowadzeniem programów łagodzenia kar doprowadził do masowego przyjmowania tego typu programów w wielu krajach. I tak, w 2018 r. programy te występowały w ponad 60 ustawodawstwach, $\mathrm{w}$ tym we wszystkich krajach należących do OECD. Dzięki tym programom szacuje się, że około $80 \%$ karteli jest wykrywanych w UE, zaś około $90 \%$ w Stanach Zjednoczonych ${ }^{6}$.

Powyższe dane, jak i rozpowszechnienie programów łagodzenia kar wydają się świadczyć o pozytywnym wpływie tych programów na wykrywalność karteli. Jednakże należy doprecyzować, że w Stanach Zjednoczonych 80-90\% wniosków o objęcie programem łagodzenia kar zostało złożonych po tym, jak departament

\footnotetext{
4 C. Harding, J. Joshua, Regulating Cartels in Europe, Oxford 2010, s. 228.

5 D. Schroeder, Squaring the circle in cartel cases: compliance, fines, leniency and settlement from a private practitioner's perspective, "Competition Policy International” 2008, 6, s. 39.

6 https://one.oecd.org/document/DAF/COMP/WP3(2018)1/en/pdf (dostęp: 15.04.2020).
} 
sprawiedliwości wszczął postępowanie7, zaś w przypadku Komisji Europejskiej było to $54 \%$ (dla okresu od 1996 do 2014 r.) ${ }^{8}$. Warto także mieć na uwadze inne dane wskazujące, że w przypadku karteli o zasięgu międzynarodowym ich przeciętny okres funkcjonowania, który kończy się skorzystaniem jednego z członków takiego kartelu z programu łagodzenia kar, to 10,3 lata i jest to najdłuższy okres funkcjonowania karteli w porównaniu z innymi przyczynami ich zakończenia9.

\section{Założenia programu łagodzenia kar}

Wzorem prawodawstwa amerykańskiego do unijnego prawa konkurencji został wprowadzony program łagodzenia kar zwany leniency. Program ten polega na dobrowolnej współpracy uczestnika kartelu z Komisją Europejską. W zamian za wyjawienie informacji o uczestnikach kartelu i przekazanie lub pomoc w zebraniu dowodów świadczących o funkcjonowaniu kartelu przedsiębiorstwo takie może uniknąć grożącej kary pieniężnej. Oczywiście można się spierać o to, że przedsiębiorstwo takie uniknie jakiejkolwiek kary za uczestnictwo w najpoważniejszym ograniczeniu konkurencji, jakie stanowią kartele, ale z drugiej strony jego zachowanie polegające na współpracy z Komisją Europejska pozwala wykryć i usankcjonować działanie takiego kartelu. Warto też dodać, że zasadniczym celem programu łagodzenia kar jest dążenie do destabilizacji karteli. Poprzez wprowadzenie tego typu programu uczestnicy kartelu obawiają się, że jeden z nich może skorzystać z zachęty w postaci uniknięcia odpowiedzialności za udział w kartelu.

Warto jednak mieć na uwadze, że cechą większości karteli jest ich niestabilność. Wiele z nich rozpada się bez udziału organów antymonopolowych właśnie z tego powodu, że jego uczestnicy nie przestrzegają przyjętych przez siebie uzgodnień. Wskazuje się, że kartele nabierają stabilności funkcjonowania wtedy, gdy są kierowane i kiedy jego uczestnicy są karani za odejście od wspólnych ustaleń ${ }^{10}$. A zatem kartele, w których nie dokonuje się weryfikacji stosowania przez jego członków przyjętych uzgodnień i brakuje lidera, który by wyznaczał sposób funkcjonowania kartelu, często rozpadają się bez żadnych działań ze strony organów antymonopo-

7 L. Marx, C. Mezzetti, R. Marshall, Antitrust Leniency with MultiProduct Colluders, „American Economics Review" 2015, 7, s. 205-240.

8 J. Zhou, The dynamics of leniency application and the knock-on effect of cartel enforcement, "Bruegel Working Paper" 2016, 2, s. 2.

9 M. Levenstein, V. Suslow, Cartels and Collusion - Empirical Evidence, "Ross School of Business Working Paper Working Paper" 2012, 1182, s. 20.

10 C. Harding, J. Joshua, op. cit., s. 230. 
lowych ${ }^{11}$. Ponadto zawsze uczestnicy kartelu mogą mieć motywację do odstąpienia od przyjętych uzgodnień. Będzie to miało miejsce np. w przypadku uzgodnienia przez kartel maksymalnej wysokości produkcji. Jeden z jego uczestników, odstępując od wspólnych uzgodnień i produkując więcej niż uzgodniono w ramach kartelu, zarobi więc więcej. Tak samo będzie w przypadku uzgodnienia przez kartel cen minimalnych albo sztywnych i prowadzenia sprzedaży przez jednego z uczestników kartelu poniżej tych wyznaczonych cen. Jeżeli więc większa ilość uczestników kartelu odejdzie od poczynionych ustaleń, po to żeby "oszukać" pozostałych, w sposób naturalnych kartel się rozpadnie ${ }^{12}$. A zatem cześć karteli przestaje istnieć bez ingerencji ze strony organów antymonopolowych właśnie z uwagi na ich niestabilność. Trudno jest także wskazać, czy programy łagodzenia kar przyczyniają się do odstraszania przed tworzeniem karteli ${ }^{13}$.

Program łagodzenia kar przyczynia się do znacznego przyśpieszenia wykrywania karteli. Ponadto dostarczone w ramach tego programu dowody powodują, że często Komisja Europejska nie musi dokonywać różnego rodzaju analiz rynkowych i badać, na którym z rynków może dochodzić do zmowy. Tym samym dzięki programom łagodzenia kar Komisja Europejska może zająć się tymi sprawami, w których żadne z przedsiębiorstw nie zdecydowało się na współpracę.

Pomimo niewątpliwie pozytywnego wpływu programów łagodzenia kar na wykrywanie karteli przez Komisję Europejską pojawiają się wątpliwości co do zasadności stosowania takiego programu we wszystkich sprawach. Typowym przykładem może być sytuacja, w której kartel przestaje działać czy gdy jego uczestniczy nie mogą dojść do konsensusu i właśnie z tego powodu jeden z nich korzysta z programu łagodzenia kar $^{14}$. A zatem uczestnik kartelu korzysta z programu łagodzenia kar tylko z tego względu, że kartel stał się dla niego bezużyteczny. Podobnie może mieć miejsce w sytuacji, gdy Komisja Europejska jest bliska wykrycia kartelu, o czym wiedzą jego uczestnicy, i właśnie z tego względu prześcigają się o to, który z nich jako pierwszy skorzysta z tego programu ${ }^{15}$. W tym miejscu można podać jeszcze jedną opinię, zgodnie z którą wysoka kara pieniężna grożąca uczestnikom kartelu może stanowić $\mathrm{w}$ istocie element stabilizujący, ponieważ będzie odstraszała od jego zakończenia ${ }^{16}$.

\footnotetext{
11 Przykładem może być tutaj sprawa Zink producers group, Dz. Urz. WE z 1984 r., L 220/27.

12 S. Colino (red.), Cartels and Anti-Competitive Agreements, t. 1, Routledge 2012, wersja elektroniczna.

13 J. Harrington Jr., Optimal Corporate Leniency Programs, "The Journal of Industrial Economics” 2008, 56, s. 238.

14 J. Basedow, Private Enforcement of EC Competition Law, Haga 2007, s. 228.

15 J. Harrington, op. cit., s. 238 i n.

16 A. Chavda, M. Jegers, The Effects of Leniency Programs and Fines on Cartel Stability, "Metroeconomica” 2007,28 , s. 232.
} 
Można również mieć wątpliwości, czy program ten zachęci uczestników karteli, które istnieją od wielu lat i przynoszą jego uczestnikom znaczne zyski. W takim właśnie przypadku wydaje się, że zachęta w postaci uniknięcia lub zredukowania kary finansowej będzie niewystarczająca. Niemniej jednak w odniesieniu do pozostałych przypadków należy stwierdzić, że już samo wprowadzenie przepisów ustanawiających program łagodzenia kar w sposób destabilizujący działa na kartele. Jego uczestnicy mogą obawiać się, że któryś z nich skorzysta z tego programu, a co za tym idzie, będą musieli liczyć się karami finansowymi. W niektórych przypadkach może więc dojść do sytuacji swego rodzaju wyścigu uczestników kartelu o skorzystanie z tego programu i uniknięcie sankcji administracyjnych. Można sobie wyobrazić nawet taką sytuację, że jeden z dotychczasowych konkurentów będący uczestnikiem kartelu decyduje się na skorzystanie z programu łagodzenia kar nie po to, by uniknąć tego typu sankcji, a po to, żeby jego konkurenci znaleźli się w dużo gorszej sytuacji finansowej poprzez konieczność zapłaty kar pieniężnych. W końcu, należy mieć na uwadze, że każdy organ antymonopolowy ma ograniczone możliwości organizacyjne i nie jest w stanie prowadzić znacznej ilości postępowań antymonopolowych. Tym samym wykrywanie poprzez program łagodzenia kar karteli może przyczynić się do tego, że pozostałe kartele zostaną wzmocnione i nie będą obawiały się wykrycia przez taki organ. Będzie to miało w szczególności miejsce w przypadku, gdy organ antymonopolowy będzie prowadził bardzo mało postępowań w sprawach, które nie są wynikiem udziału jednego z przedsiębiorstw w programie łagodzenia kar ${ }^{17}$.

Wskazuje się jednak, że w tych państwach członkowskich, które wprowadziły kary, tj. karę pozbawienia wolności bądź bardzo wysokie grzywny grożące osobom podejmującym decyzje kierownicze w przedsiębiorstwach, skorzystanie z programu łagodzenia kar będzie właśnie ograniczone z uwagi na obawę przed tego typu odpowiedzialnością ${ }^{18}$.

W konkluzji należy wskazać, że program łagodzenia kar został zaprojektowany w celu ułatwienia wykrywania karteli, przede wszystkim poprzez ich destabilizację. Przeprowadzanie kontroli, badania rynku, tak jak w każdym postępowaniu, są czasochłonne. Jeżeli jeszcze dojdą do tego zachowania przedsiębiorstw utrudniające zebranie dowodów, poprzez np. wprowadzanie Komisji Europejskiej w błąd, niszczenie czy zatajanie dowodów, to prowadzenie takich postępowań będzie bardzo długie. Natomiast w przypadku objęcia uczestnika kartelu programem łagodzenia kar Komisja Europejska dostaje dowody od takiego przedsiębiorstwa, które

17 C. Myong-Hun, J. Harrington, The Impact of a Corporate Leniency Program on Antitrust Enforcement and Cartelization, http:/www.econ2.jhu.edu/People/Harrington/leniency_4.10.pdf (dostęp: 3.04.2020).

18 M. Furse, S. Nash, The Cartel Offence, London 2004, s. 70. 
dodatkowo są bardzo trudne do podważenia przez pozostałych uczestników kartelu. Poprzez możliwość udziału programie łagodzenia kar niektórzy członkowie kartelu mogą więc zabezpieczać się poprzez zebranie rożnego rodzaju dowodów wskazujących na funkcjonowanie kartelu ${ }^{19}$.

Programy łagodzenia kar wprowadzono też w celu ochrony interesu publicznego. Kartele negatywnie wpływają na gospodarkę, nie tylko pozbawiając konsumentów tańszych produktów i usług o wyższej jakości, ale także ograniczają miejsca pracy. Dlatego dla organów ochrony konkurencji niezbędne jest wykrywanie i sankcjonowanie karteli. Oznacza to, że ukaranie uczestnika kartelu nie jest tak ważne, jak samo wyeliminowanie kartelu.

\section{Całkowite zwolnienie z kary}

Najbardziej atrakcyjne dla przedsiębiorstw chcących skorzystać z programu łagodzenia kar jest uzyskanie całkowitego zwolnienia z kary. Skorzystanie jednak z tego typu przywileju uwarunkowane jest zgłoszeniem się jako pierwszy uczestnik kartelu do Komisji Europejskiej z wnioskiem o objęcie tym programem. Oczywiście możliwość objęcia programem łagodzenia kar przewidującym całkowite zwolnienie z kar możliwe jest jedynie wtedy, gdy Komisja Europejska nie posiada informacji i dowodów na istnienie określonego kartelu.

Unijne prawo konkurencji, wzorem prawa amerykańskiego, wymaga, aby przedsiębiorstwo chcące skorzystać z programu łagodzenia kar przekazało Komisji Europejskiej bardzo szczegółowe informacje o kartelu. A zatem uczestnik ten powinien przekazać Komisji Europejskiej takie informacje, jak: informacje o działalności kartelu, jego celach, sposobach działania, objętych nim produktach lub usługach, rynkach, na którym działa kartel, okresie, w jakim kartel działa lub działał, oraz dokładne informacje o uczestnikach kartelu, miejscach dokonywania uzgodnień, kontaktach uczestników kartelu oraz wszelkie inne dowody związane z kartelem. Ponadto zakres przekazywanych informacji zależeć będzie od samej Komisji Europejskiej, która to określać będzie, jakiego rodzaju informacje powinno przekazać przedsiębiorstwo korzystające z programu łagodzenia kar. Natomiast jeżeli przedsiębiorstwo nie będzie w stanie takich informacji zebrać, to przynajmniej powinno przedstawić Komisji Europejskiej szczegółowe wskazówki umożliwiające przeprowadzenie kontroli.

19 B. Balasingham, The EU Leniency Policy: Reconciling Effectiveness and Fairness, Hague 2016, wersja elektroniczna. 
Tak określone obowiązki przedsiębiorstwa objętego programem łagodzenia kar wskazują, że w zasadzie to przedsiębiorstwo będzie podmiotem odpowiedzialnym za zebranie dowodów wskazujących na istnienie kartelu. Wskazuje się jednak, że zadanie to wcale nie musi być takie łatwe, bowiem będzie wymagało, aby kierownictwo przedsiębiorstwa poleciło określonym pracownikom zebranie informacji od ich wieloletnich parterów handlowych. Może się zatem okazać, że pracownik takiego przedsiębiorstwa nie będzie chciał podejmować działań, które zaszkodzą osobie zatrudnionej na podobnym stanowisku u innego członka kartelu, z którą to przez wiele lat wspólpracował ${ }^{20}$.

Programem łagodzenia kar zakładającym całkowite zwolnienie z grzywny nie mogą być objęte te przedsiębiorstwa, które nakłaniały inne przedsiębiorstwa do udziału w kartelu lub pozostania w nim. Tym samym z tego programu nie będzie mógł skorzystać inicjator kartelu lub przedsiębiorstwo, które było liderem kartelu, zapraszając do jego udziału innych uczestników. Rozwiązanie to wydaje się zasadne. Oczywiście zawsze można twierdzić, że dzięki programom łagodzenia kar zawsze odciąża się organy antymonopolowe, ale można też wskazać, że określone przedsiębiorstwo dopuściło się tylu naruszeń prawa konkurencji, iż niezbędne jest jego ukaranie.

\section{Częściowe zwolnienie z grzywny}

Jak już wspomniano, pierwsze przedsiębiorstwo, które zgłosi się do Komisji Europejskiej, może ubiegać się o udział w programie łagodzenia kar umożliwiający pełną jej redukcję. Nie oznacza to jednak, że pozostałe przedsiębiorstwa uczestniczące w kartelu nie będą miały szansy podjęcia współpracy z Komisją Europejską w ramach tego typu programu, z tą różnicą, że mogą one uzyskać zmniejszenie grzywny. I tak, o zmniejszenie kary pieniężnej mogą ubiegać się trzy pierwsze przedsiębiorstwa, jeżeli oczywiście spełniają przesłanki objęcia tym programem. Wobec takich przedsiębiorstw Komisja Europejska może zmniejszyć karę pieniężną w następujących wysokościach:

$\square$ dla pierwszego przedsiębiorstwa o $30-50 \%$,

$\square$ dla drugiego przedsiębiorstwa o $20-30 \%$,

$\square$ dla trzeciego przedsiębiorstwa do $20 \%$.

20 A. Kayhko, The European Commission's 2006 Leniency Notice - for better or for worse?, "Competition Law International" 2008, 6, s. 44. 
Zasadniczą przesłanką objęcia tego typu programem łagodzenia kar jest przekazanie przez przedsiębiorstwo Komisji Europejskiej dowodów na istnienie kartelu, które to przyczyniają się do znaczącego zwiększenia wartości dowodów będących już w posiadaniu Komisji. A zatem nie chodzi tu wyłącznie o chęć nawiązania współpracy z Komisją Europejską i już z tego powodu otrzymanie zmniejszenia grzywny, a o przedstawienie dowodów, które jeszcze bardziej przyczynią się do udowodnienia naruszenia. $\mathrm{W}$ obwieszczeniu w sprawie zwalniania $\mathrm{z}$ grzywien i zmniejszania grzywien w sprawach kartelowych Komisja Europejska wskazała, że chodzi tu przede wszystkim o dowody pisemne z okresu domniemanego naruszenia czy bezpośrednie dowody odnoszące się do stanu faktycznego ${ }^{21}$. W zasadzie można stwierdzić, że znaczna wartość dowodowa jest kryterium ocennym, które to zależy od zgromadzonych przez Komisję Europejską dowodów. Może się więc okazać, że uczestnik kartelu, który uzyskał całkowite zwolnienie z kary pieniężnej, niewątpliwie doprowadził do wykrycia kartelu, jednak jego rola mogła nie być znaczna i tym samym nie był w stanie zgromadzić bardzo szczegółowych dowodów świadczących o istnieniu kartelu. Właśnie w takim przy padku kolejne trzy przedsiębiorstwa mogą zaoferować Komisji Europejskiej przekazanie dowodów, które w znaczny sposób wzmocnią materiał dowodowy poprzez potwierdzenie z wykorzystaniem innych źródeł.

Dokonując analizy tego programu, należałoby się zastanowić, na ile częściowe zwolnienie z grzywny przyczynia się do zarówno wykrywalności karteli, jak i skrócenia postępowań antymonopolowych. Przede wszystkim należy wskazać, że Komisja Europejska nie uzyska tak przełomowych informacji, jak w przypadku programu zakładającego całkowite zwolnienie z kary pieniężnej. Będzie on zawsze stanowił sposób uzupełnienia materiału dowodowego, w którego posiadaniu Komisja Europejska już jest. Można więc stwierdzić, że program ten przyczynia się do zmniejszenia wysiłków Komisji Europejskiej związanych ze zbieraniem dowodów i w tym sensie przyczynia się do szybszego zakończenia postępowań antymonopolowych.

Należy jednak mieć na uwadze pewną wadę tego typu programu łagodzenia kar. A mianowicie skoro zachętą dla przedsiębiorstw ma być objęcie pełnym zwolnieniem z kary pieniężnej, która to ma skutkować destabilizacją karteli, powodując niejako „wyścig” jego uczestników po skorzystanie z tego programu, to funkcjonowanie częściowego zwolnienia z grzywny niewątpliwie wyścig ten osłabia, zmniejszając zachętę za przekazanie informacji o istnieniu kartelu ${ }^{22}$. Poza tym

\footnotetext{
21 Obwieszczenie Komisji w sprawie zwalniania z grzywien i zmniejszania grzywien w sprawach kartelowych Dz. Urz. UE z 2006 r., C 298/11.

22 C. Lavoie, South Africa's Corporate Leniency Policy: A Five-Year Review, „World Competition” 2009, 1, s. 146.
} 
twierdzi się, że w przypadku najpoważniejszych karteli, którymi są najczęściej kartele ustalające ceny odsprzedaży, to wysokie kary pieniężne odstraszają przedsiębiorstwa od tworzenia tego typu karteli ${ }^{23}$. Natomiast w przypadku wprowadzenia do systemu prawnego programu łagodzenia kar umożlwiającego uzyskanie częściowej, ale nadal wysokiej redukcji kary pieniężnej takiego efektu odstraszającego nie będzie, ponieważ każdy uczestnik kartelu będzie liczył na to, że w najgorszym scenariuszu, skorzysta z częściowego zwolnienia i tym samym będzie musiał uiścić jedynie $50 \%$ grożącej mu kary.

W tym miejscu warto odwołać się do modelu amerykańskiego, który ma jedynie program łagodzenia kar zakładający pełną jej redukcję i to tylko dla pierwszego przedsiębiorstwa, które zakwalifikuje się do udziału w takim programie. Departament sprawiedliwości może jednak obniżyć wymiar takiej kary właśnie w zamian za współpracę przedsiębiorstwa, która kończy się ugodą, co nieco nawiązuje do unijnego programu przewidującego częściowe zwolnienie z grzywny. Taką częściową redukcję zastosowano w około 66\% spraw dotyczących karteli, jednakże o wysokości zastosowanej redukcji decydowały inne niż w przypadku programu unijnego kryteria. I tak, wysokość częściowej redukcji uzależniona była od kolejności zgłoszenia przedsiębiorstwa, długości negocjacji pomiędzy departamentem sprawiedliwości a przedsiębiorstwem oraz zasięgiem danego kartelu - kartele o zasięgu międzynarodowym otrzymywały znacznie mniejsze redukcje kary finansowej niż kartele o zasięgu wyłącznie krajowym ${ }^{24}$. Wynika z tego, że w amerykańskim prawie konkurencji w bardziej elastyczny sposób podchodzi się do oceny wkładu przedsiębiorstwa w szybsze zakończenie postępowania, przyznając redukcję w grzywnie już za samo szybkie przyznanie się do udziału w kartelu.

\section{Leniency plus i penalty plus}

W prawie konkurencji UE brakuje rozwiązań przyjętych w wielu ustawodawstwach, które to rozszerzają stosowanie programu lagodzenia kar. W Stanach Zjednoczonych został wprowadzony program Leniency (amnesty) plus. Program ten skierowany jest do tych przedsiębiorstw, które nie zostały objęte programem łagodzenia kar przyznających całkowitą redukcję kary pieniężnej. W zamian za przekazanie organowi antymonopolowemu informacji o kartelu istniejącym na innym rynku

23 F. Easterbrook, W. Landes, R. Posner, Contribution among Antitrust Defendants: A Legal and Economic Analysis, "Journal of Law and Economics” 1980, 23, s. 331-370; W. Wils, Is Criminalization of EU Competition Law the Answer?, "World Competition” 2005, 28, s. 117-159.

24 J. Connor, A Critique of Partial Leniency for Cartels by the U.S. Department of Justice, ",SSRN Electronic Journal" 2007, 4, s. 45-46. 
przedsiębiorstwo otrzymuje zarówno złagodzenie kary za udział w tym kartelu, jak też dodatkowo redukuje mu się karę za udział w pierwszym kartelu. Oczywiście objęcie programem Leniency plus może nastąpić, jeżeli przedsiębiorstwo spełnia warunki objęcia zasadniczym programem Leniency w odniesieniu do tego drugiego kartelu, o którego istnieniu poinformowało organ antymonopolowy.

Program ten jest przede wszystkim skierowany do przedsiębiorstw działających na różnych rynkach, wobec których toczy się postępowanie antymonopolowe i umożliwia przedsiębiorstwom przyznanie się do naruszeń prawa konkurencji, które mają miejsce na innych rynkach niż ten, którego dotyczy postępowanie ${ }^{25}$. Warto jednak podkreślić istotną różnicę pomiędzy amerykańskim a unijnym programem łagodzenia kar jaką jest to, że w Stanach Zjednoczonych tylko jedno przedsiębiorstwo może skorzystać z programu łagodzenia kar i nie jest możliwe uzyskanie przez kolejne przedsiębiorstwa nawet częściowej jej redukcji ${ }^{26}$. Stąd program Leniency plus jest jedyną możliwością na zredukowanie wymiaru kary pieniężnej grożącej przedsiębiorstwom, które nie zostały objęte zasadniczym programem łagodzenia kar. Nierozłącznym elementem programu Leniency plus jest program Penalty plus, zakładający, że przedsiębiorstwu, które nie skorzysta z programu Leniency plus i nie wyjawi organowi antymonopolowemu informacji o udziale $\mathrm{w}$ innych kartelach, a udział ten zostanie wykryty, grozi znacznie surowsza kara ${ }^{27}$.

Cel programu Leniency plus jest taki sam jak zasadniczego programu Leniency plus, a mianowicie wyjawienie informacji o kartelach i otrzymanie za to redukcji grożącej przedsiębiorstwu kary finansowej. Należy jednak mieć na uwadze, że programem tym mogą być objęte te przedsiębiorstwa, wobec których toczy się już postępowanie antymonopolowe, a zatem przedsiębiorstwa te niejako zostały przymuszone do skorzystania $\mathrm{z}$ tego programu, bowiem ich udział w kartelu został wykryty. Ponadto skorzystanie z programu Leniency plus może być wynikiem obaw przedsiębiorstwa, że jego udział w innych kartelach może być wyjawiony przez jednego z uczestników kartelu, który już skorzystał z programu łagodzenia kar $^{28}$.

25 M. LeClair, Cartelization, Antitrust and Globalization in the US and Europe, Routledge 2011, s. 108.

26 J. Buhart (red.), Leniency Regimes: Jurisdictional Comparisons, London 2012, s. 388.

27 C. Roux, T. von Ungern-Sternberg, Leniency Programs in a Multimarket Setting: Amnesty Plus and Penalty Plus, ,"CESifo Working Paper Series" 2007, 1995, SSRN: https://ssrn.com/abstract=992686, s. 4 (dostęp: 17.04.2020.

28 K. Ewing, Competition Rules for the 21st Century - Principles from America's Experience, Hague 2006, s. 578. 


\section{Odrębność programów łagodzenia kar państw członkowskich}

Skorzystanie przez przedsiębiorstwo z programu łagodzenia kar nie oznacza, że przedsiębiorstwo to uzyskało niejako ochronę przed nałożeniem kary, ponieważ zgodnie z obwieszczeniem dotyczącym Europejskiej Sieci Konkurencji programy łagodzenia kar prowadzone przez Komisję Europejską i organy antymonopolowe państw członkowskich są od siebie niezależne i od siebie odrębne. Takie rozwiązanie powoduje, że uczestnik kartelu, aby mógł uniknąć odpowiedzialności za udział w kartelu, powinien jako pierwszy złożyć wniosek o objęcie programem łagodzenia kar u wszystkich organów antymonopolowych, które mogą wszcząć postępowanie antymonopolowe przeciwko niemu ${ }^{29}$. A zatem w praktyce może być problematyczne to, żeby określone przedsiębiorstwo zdążyło jako pierwsze złożyć taki wniosek, w szczególności w sytuacji, gdy działalność kartelu jest już zdestabilizowana. Ponadto, składając wniosek o objęcie programem łagodzenia kar do poszczególnych organów antymonopolowych państw członkowskich, przedsiębiorstwo nie będzie miało pewności, że jako pierwsze złożyło taki wniosek i zostanie objęte programem łagodzenia $\mathrm{kar}^{30}$. Warto także podkreślić, że w niektórych ustawodawstwach państw członkowskich odpowiedzialność za udział w kartelu spoczywa nie tylko na przedsiębiorstwie, ale także na osobach pełniących funkcje kierownicze w przedsiębiorstwie, które podjęły decyzję o udziale w kartelu. Jeżeli w niektórych państwach członkowskich na takie osoby może być nałożona wysoka kara finansowa lub nawet kara pozbawienia wolności, to brak pewności objęcia programem łagodzenia kar w każdym właściwym państwie członkowskim może być powodem rezygnacji przez przedsiębiorstwo z udziału $\mathrm{w}$ takim programie.

Warto również dodać, że na podstawie art. 11 ust. 3 rozporządzenia nr 1/2003 informacje o kartelu, które przekazało przedsiębiorstwo korzystające z programu łagodzenia kar w jednym z państw członkowskich, mogą być udostępnione zarówno Komisji Europejskiej, jak i pozostałym państwom członkowskim, tyle że nie mogą one posłużyć do wszczęcia przeciwko temu przedsiębiorstwu postępowania antymonopolowego.

29 C. Gauer, M. Jaspers, The European Competition Network. Achievements and challenges - a case in point: leniency, "Competition Policy Newsletter" 2006, 1, s.10.

30 Przemowa Komisarz M. Vestager, Perspectives on Europe, London School of Economics, 20 listopada 2015, https://wayback.archive-it.org/12090/20191129203224/https://ec.europa.eu/commission/commissioners/2014-2019/vestager/announcements/perspectives-europe_en (dostęp: 17.04.2020). 


\section{Podsumowanie}

Programy lagodzenia kar w bardzo istotny sposób przyczyniają się do wykrywania karteli przez Komisję Europejską. Ich funkcjonowanie powoduje, że uczestnicy karteli stają się nieufni wobec siebie, co prowadzi do destabilizacji karteli. W przypadku, gdy kartelowi grozi rozpad, zaczyna się swego rodzaju „wyścig” do organu antymonopolowego przedsiębiorstw o objęcie takim programem. Programy te przyczyniły się w Unii Europejskiej i w Stanach Zjednoczonych do wykrycia wielu karteli.

Niemniej jednak warto mieć na uwadze, że „sukces” programów łagodzenia kar wywołuje również negatywne skutki. Komisja Europejska rzadziej sięga do innych sposobów wykrywania karteli, oczekując niejako przekazania jej informacji o kartelu od samych przedsiębiorstw. Powoduje to, że niektóre kartele wręcz mniej obawiają się działań ze strony Komisji Europejskiej, co powoduje ich wzmocnienie. Można więc stwierdzić, że programy łagodzenia kar nie powinny stanowić zasadniczego sposobu wykrywania karteli, a jedynie jedno z narzędzi, którymi dysponuje Komisja Europejska. Korzystanie tylko z tych programów przyczyni się głównie do wykrycia jedynie tych karteli, w których uczestnicy nie zawsze będą osiągali znaczne zyski, stąd jeden z nich zdecyduje się na ograniczenie swojej odpowiedzialności. Natomiast w przypadku karteli tajnych, których uczestnicy przez wiele lat osiągają znaczne zyski, program łagodzenia kar może być często niewystarczający do ich wykrycia. Jak już wspomniano na wstępie, średni okres funkcjonowania kartelu, który został wykryty dzięki programom łagodzenia kar, to 10,3 roku, trudno więc uznać, że programy te przyczyniają się do szybszego wykrywania karteli. Jest wręcz przeciwnie - rozpad karteli spowodowany innymi powodami, w tym wykryciem przez organa antymonopolowe jest krótszy. Może się więc okazać, że program łagodzenia kar przyczynia się w znacznej części do wykrycia tych karteli, które i tak by się rozpadły, ponieważ ich uczestnicy nie zamierzają dalej ze sobą współpracować.

Zasadniczą wadą unijnego programu łagodzenia kar jest to, że nie obejmuje on programu Leniency plus funkcjonującego w innych krajach. Dzięki takiemu programowi Komisja Europejska mogłaby uzyskać dowody na istnienie wielu innych karteli. Co więcej, wadą unijnych rozwiązań jest brak harmonizacji pomiędzy programem łagodzenia kar prowadzonym przez Komisję Europejską a programami prowadzonymi przez organa antymonopolowe państw członkowskich, co zaś uniemożliwia ocenę, czy przedsiębiorstwo, które chce skorzystać z takiego programu, złoży wniosek jako pierwsze do każdego z tych organów. A zatem objęcie programem prowadzonym przez Komisję Europejska nie chroni przedsiębiorstw przed postępowaniami w państwach członkowskich. Tak istotne wady rozwiązań 
unijnych skłaniają do wniosku, że niezbędne jest zharmonizowanie programów łagodzenia kar w całej UE i przyjęcie określonych zasad, że złożenie wniosku do Komisji Europejskiej oznacza automatycznie „zarezerwowanie” udziału w programach prowadzonych przez poszczególne państwa członkowskie.

\section{Bibliografia}

Balasingham B., The EU Leniency Policy: Reconciling Effectiveness and Fairness, Hague 2016. Basedow J., Private Enforcement of EC Competition Law, Hague 2007.

Buhart J. (red.), Leniency Regimes: Jurisdictional Comparisons, London 2012.

Chavda A., Jegers M., The Effects of Leniency Programs and Fines on Cartel Stability, "Metroeconomica" 2007, 28.

Colino S. (red.), Cartels and Anti-Competitive Agreements, t. 1, Routledge 2012.

Connor J., Cartel Detection and Duration Worldwide, "Antitrust Chronicle” 2011, 9.

Connor J., A Critique of Partial Leniency for Cartels by the U.S. Department of Justice, "SSRN Electronic Journal" 2007, 4.

Easterbrook F., Landes W., Posner R., Contribution among Antitrust Defendants: A Legal and Economic Analysis, "Journal of Law and Economics" 1980, 23, s. 331-370;

Ewing K., Competition Rules for the 21st Century - Principles from America's Experience, Hague 2006.

Furse M., Nash S., The Cartel Offence, London 2004.

Gauer C., Jaspers M., The European Competition Network. Achievements and challenges - a case in point: leniency, "Competition Policy Newsletter" 2006, 1.

Harding C., Joshua J., Regulating Cartels in Europe, Oxford 2010.

Harrington J., Jr., Optimal Corporate Leniency Programs, „The Journal of Industrial Economics" 2008, 56.

Kayhko A., The European Commission's 2006 Leniency Notice - for better or for worse?, "Competition Law International" 2008, 6.

Lavoie C., South Africa's Corporate Leniency Policy: A Five-Year Review, „World Competition" 2009, 1.

LeClair M., Cartelization, Antitrust and Globalization in the US and Europe, Routledge 2011.

Levenstein M., Suslow V., Cartels and Collusion - Empirical Evidence, "Ross School of Business Working Paper Working Paper" 2012, 1182.

Marx L., Mezzetti C., Marshall R., Antitrust Leniency with MultiProduct Colluders, „American Economics Review" 2015, 7, s. 205-240.

Myong-Hun C., Harrington J., The Impact of a Corporate Leniency Program on Antitrust Enforcement and Cartelization, http:/www.econ2.jhu.edu/People/Harrington/ leniency_4.10.pdf (dostęp: 3.04.2020).

Roux C., Ungern-Sternberg T., von, Leniency Programs in a Multimarket Setting: Amnesty Plus and Penalty Plus, CESifo Working Paper Series No. 1995/2007, SSRN: https:// ssrn.com/abstract=992686 (dostęp: 17.04.2020). 
Schroeder D., Squaring the circle in cartel cases: compliance, fines, leniency and settlement from a private practitioner's perspective, "Competition Policy International" 2008, 6. Vestager M., Perspectives on Europe [przemowa], London School of Economics, 20 listopada 2015, https://wayback.archive-it.org/12090/20191129203224/https://ec.europa. eu/commission/commissioners/2014-2019/vestager/announcements/perspectives-europe_en (dostęp: 17.04.2020).

Wils W., Is Criminalization of EU Competition Law the Answer?, "World Competition" 2005, 28, s. 117-159.

Zhou J., The dynamics of leniency application and the knock-on effect of cartel enforcement, „Bruegel Working Paper” 2016, 2. 